УДК: 81:929 Белић А.

061.12(497.11)"1920/1959"(093.2)

DOI: https://doi.org/10.18485/belic_slv.2017.2.ch1

Бојан Ђорђевић

\title{
АЛЕКСАНДАР БЕЛИЋ И СТРАНИ СЛАВИСТИ У СРПСКОЈ АКАДЕМИЈИ НАУКА И УМЕТНОСТИ
}

Александар Белић је у свом дугогодишњем деловању у Српској краљевској академији (Српској академији наука и уметности) био један од најактивнијих заступника идеје о потреби да се заслужни страни слависти приме у ред дописних иностраних академика, не би ли се тако ојачала веза домаће лингвистичке и књижевноисторијске науке са страном. Доказ тога јесте и његово залагање за пријем у Академију више страних слависта из разних земаља - Русије, САД, Немачке, Чешке, Пољске. Документа везана за пријем ових слависта чувају се данас у Архиву Српске академије наука и уметности, као и у Академијиној библиотеци. Ова грађа сведочи о Белићевој доследности и посвећености задатку који је он схватао као културно прегнуће од изузетног значаја. За десетак слависта Белић је лично писао предлог за пријем у Академију, а онда тај предлог на одговарајућим седницама и образлагао. Захваљујући Белићевој иницијативи, дописни инострани чланови Српске краљевске академије, тј. Српске академије наука и уметности, постали су пре Другог светског рата Антоан Меје, Олаф Брок, Стјепан Куљбакин, Јозеф Зубати, Казимир Њич, Олджих Хујер, Тадеуш Лер-Сплавињски, а после Другог светског рата Андре Вајан, Роман Јакобсон, Андре Мазон, Јиржи Курилович и Виктор Владимирович Виноградов. На предлог Александра Белића, Стјепан Куљбакин је, примивши југословенско држављанство, постао и редовни члан Српске краљевске академије.

Документи које доносимо у нашем раду сведоче о томе да је Александар Белић предано пратио рад поменутих слависта, да је био упућен у све токове тадашње филолошке науке у свету, те да је брижљиво процењивао и суптилно оцењивао допринос страних слависта не само филолошкој науци уопште већ и јужнословенској филологији. Такође, његово залагање да се у Академију приме пољски научници, попут Тадеуша Лер-Сплавињског, у часу када је Пољска била брутално нападнута од стране нацистичке 
Немачке, говори о снажном патриотизму и хуманизму, те представља културолошки податак првог реда о спремности самога Белића, али и других српских интелектуалаца, да се и на овакав, симболичан начин, искаже солидарност са страдалничким и братским народом. Стога сматрамо корисним објављивање оригиналних докумената који сведоче о Белићевом залагању за тесне везе наше и европске славистике, које су посведочене и чињеницом да су - умногоме захваљујући тадашњем председнику Академије - место у највишој српској научној и културној институцији нашли највиђенији научници и слависти свога времена.

Предлози за избор дописних иностраних чланова Српске краљевске академије (Српске академије наука и уметности) које је формулисао, писао и на седницама Академије образлагао Александар Белић.

Предлог за избор А. Мејоа [Mејеа], О. Брока и С. Куљббакина. Предлагачи: Љ. Стојановић и А. Белић. Писано руком љ. Стојановића. 17. јануар 1920. ${ }^{1}$

A. Meillot [Meje], данашњи је највећи лингвиста не само у Француској, него један од највећих у целом свету.

Олафа Брока, проф. Унив. у Христијанији и заслужног испитивача фонетике словенских језика.

Степана Михајловића Куљбакина, проф. Харковског Универзитета и једног од најистакнутијих руских слависта који су предавали јужнословенске језике. ${ }^{2}$

Предлог за избор С. Кульбакина за редовног члана. Предлагачи: А. Белић, Н. Вулић и Љ. Стојановић. Писано руком А. Белића. 16. јануар 1925.

\footnotetext{
1 Текст докумената доноси се без измена.

2 Меје, Брок и Куљбакин изабрани су за дописне иностране чланове 16. фебруара 1920. године.
} 
Данас је професор Куљбакин један од најистакнутијих слависта у свету и у извесним пословима (на пр. познавању и испитивању старословенског језика), можда, најбољи.

Спрема г. Куљбакина врло је широка. Он у себи сједињује и филолога и лингвисту, тако да за послове наше Академије може бити врло користан.

Његови су радови многобројни. Без престанка он ради на упоредној граматици словенских језика, издавању и проучавању старословенских текстова, и проучавању свих питања која се тичу савремене словенске лингвистике и филологије.

Г. Куљбакин је не само професор Београдског Универзитета него и наш поданик. ${ }^{3}$

Говор А. Белића на Трећем скупу САНУ за 1927. годину у част редовног члана С. Куљбакина. 10. фебруар 1927.

Г. Г. Академици, поштоване госпође и господо.

Г. Стеван Куљбакин, професор славистике Универзитета у Београду, већ тридесет година са успехом ради на науци. Он је цео живот свој посветио проучавању словенских језика, а међу њима на првом месту проучавању јужнословенских језика.

Међу свима јужнословенским језицима најзнатнији је за проучавање наше језичке прошлости старословенски језик, који је по својим споменицима најстарији словенски језик уопште и који је био, и код Срба и код Хрвата, језиком цркве, а код једног дела Срба и књижевним језиком све до XVIII века.

Томе језику, како се он јавља у најстаријим споменицима и како се развио доцније у споменицима македонским, бугарским и српским, г. Куљбакин је посветио највећи део свога живота и рада, описујући старе споменике његове са језичке и палеографске стране, и дајући компендиуме, као што је његова старословенска граматика, о језику целих група тих споменика. Једна је од првих расправа г. Куљбакина о језику нашег Вукановог Јеванђеља, једно је од његових најдубљих испитивања - о језику Охридског Апостола, једног споменика југозападне Македоније, заједно са врло тачним издањем тога споменика, а једно је од последњих његових дела, у издањима Српске Краљевске Академије - о језику и палеографији опет нашег Мирослављева Јеванђеља.

${ }^{3}$ Куљбакин је за редовног члана изабран 16. фебруара 1925. године. 
Али научни рад и научно интересовање г. Куљбакина прелази знатно границе језика и палеографије старословенских споменика у различним редакцијама старословенског језика. Он се бавио, са великим успехом, проучавањем и свих осталих словенских језика, а нарочито пољског и чешког језика, руског језика, а нарочито његова украјинског или малоруског диалекта. Он је један од врло истакнутих испитивача словенског акцента, један од врло малога броја оних који су ушли у сложену систему акценатских промена у свима словенским језицима. Г. Куљбакин представља, у исто време, и одличног словенског филолога, који влада у потпуности савременим методима рада. Та веза обеју страна језичних испитивања ретка је код научника који се баве језиком. Све ово дало је врло солидну репутацију г-ну Куљбакину у европској науци једног од најбољих данашњих познавалаца старословенског језика.

Пред Српском Краљевском Академијом стоје многобројни задаци у вези са проучавањем, издавањем, описивањем и сређивањем великог броја, који иде у хиљаде, наших старих споменика, растурених по целоме свету. Ретко да која европска већа библиотека нема по неколико или по коју десетину, а каткада и знатно више, наших старих споменика. Овај посао, рађен на махове и делимично у различним словенским земљама, у потпуности и систематски није још урађен.

Српска Краљевска Академија, бирајући г-на Куљбакина за свога редовнога члана, хтела је да покаже, пре свега, колико она цени проучавање наших старих споменика и нашег и осталих словенских језика, а затим, и више од свега, како високо она ставља учешће г-на Куљбакина у том раду уопште. Али ја мислим да нећу открити никакву тајну, ако додам да се у овоме њену избору, сем свега другога, огледа и њено оправдано уверење да ће овако, имајући у својој средини г-на Куљбакина, у будуће још ближе и још јаче везати за извршење својих задатака у проучавању старословенског језика и рад овог одличног стручњака.

4.

Предлог за избор Ј. Зубата [Зубатија]. Предлагачи: А. Белић, Ж. Павловић, Љ. Стојановић, Ј. Н. Томић, С. Јовановић и Н. Вулић. Писано руком А. Белића. 24. јануар 1926. 
Јозеф Зубато [Зубати], председник Чешке Академије Наука. У словенској филологији и словенској лингвистици он је најистакнутији научник код Чеха. Као лингвиста, који се бавио упоредном граматиком и индиским језиком, Зубати има солидну репутацију у светској науци. Он се бави специално синтаксом и семазиологијом и дао је велики број радова од несумњиве вредности. Иако је навршио седамдесет година живота, он је још врло активан. Откако је умро Гебауер он је централна личност чешке филологије и лингвистике, око које се у Чешкој купе сви старији и млађи научници који модерно на овом делу науке раде. Бирајући њега, Српска Краљевска Академија одаће признање једном ретком научнику, који је врло много урадио на томе да чешка наука дође у непосредну везу са европском науком и да се у чешкој науци одомаће и развију савремени правци лингвистичких испитивања. ${ }^{4}$

5.

Предлог за избор К. Њича. Предлагачи: А. Белић, В. Петковић и J. Ердельновић. Писано руком А. Белића. 26. јануар 1936.

Казимир Њич, професор Универзитета у Кракову. После смрти Јана Розвадовског, нашег дописног члана, и истакнутог пољског лингвисте - несумњиво најугледније место заузима у пољској лингвистичкој науци професор Њич, чији је шездесетогодишњи јубилеј прославила пољска наука крајем 1934. године. Он је оснивач пољске дијалектологије и један од најбољих организатора научног лингвистичког рада у Пољској. И данас још води он часопис Пољски језик, посвећен научним испитивањима о пољском језику, Словенски народ, посвећен дијалектологији и етнографији свих словенских народа; он је један од уредника Славистичког годишњака који је, нарочито пре рата, имао великих заслуга; најзад, његова је заслуга што је Пољска Академија Наука посветила велики број својих издања и својих помоћи о проучавању историје и савременог стања пољског језика, његовој дијалектологији и језичкој географији. Сва се његова дела одликују сигурношћу и проницљивошћу. Њихов списак износи око четири стотине већих и мањих радова. Српска Краљевска Академија, бирајући г-на Казимира Њича за дописног члана, извршиће

${ }^{4}$ Зубати је изабран за дописног иностраног члана 18. фебруара 1920. године. 
само акт правичности и поштовања према овоме научнику који је својим радом, у знатној мери, задужио и нашу науку. ${ }^{5}$

6.

Предлог за избор О. Хујера. Предлагачи: А. Белић, В. Петковић и J. Ердельновић. Писано руком А. Белића. 26. јануар 1936.

Олджих Хујер, професор Карлова Универзитета у Прагу, заузима несумњиво једно од најугледнијих места у чешкој лингвистици. Бави се упоредном граматиком и проучавањем историје чешког језика; има много радова из етимологије и морфологије. Истакао се необично својим радовима о прасловенском језику. Његова Словенска енциклопедија једна је од најбољих књига, и по поузданости и по здравом критицизму, из словенске упоредне граматике. Његов Увод у историју чешког језика - у исто је време и увод у историју свих словенских језика. То је кратка, врло критично израђена, граматика прасловенског језика. Сем рада на упоредној граматици индоевропских језика, проф. Хујер је као ретко ко устопице пратио сва важнија дела која се тичу целокупне упоредне граматике индоевропских језика. Он много година води библиографију словенске лингвистике у Indogerm. Jacherbuch-y, у Филол. Зборнику Чешке Академије Наука, заједно са проф. Мурком издаје већ 13 година највећи славистички часопис Славију и, после смрти Јозефа Зубатија, он је централна личност чешке лингвистике. Преглед његових радова од 1901-1930 год. у Ј. Фил. /1930/ 327-343. И после 1930 год. он је продужио рад у свима тако означеним правцима. Сматрамо да је у интересу и наше науке и наших узајамних научних односа са чехословачким народом да бирањем г-на О. Хујера за дописног члана одамо признање овом даровитом и заслужном научнику. ${ }^{6}$

7.

Предлог за избор Т. Л. Сплавиғьског. Предлагачи: А. Белић, Н. Вулић, В. Петковић, Т. Ђорђевић, Ј. Ердељьновић и С. Кульбакин. Машинопис. 29. јануар 1940.

${ }^{5}$ Њич је за дописног иностраног члана изабран 17. фебруара 1936. године.

${ }^{6}$ Хујер је за дописног иностраног члана изабран 17. фебруара 1936. године. 
Академија философских наука једногласно предлаже Тадеуша Лера Сплавињског, ректора Краковског универзитета и професора, за дописног члана.

Г. Тадеуш Лер Сплавињски заузима једно од првих места у данашњој пољској лингвистици и једно од истакнутих места у славистици уопште. Он је посветио цео низ испитивања словенској акцентологији, у којој једно од првих места заузима наш језик са својим архаичним говорима. Затим се бавио испитивањем старословенског језика, старих дијалекатских споменика пољског језика, развитка пољског језика уопште и његова данашњег стања. Он је на челу издања савременог пољског речника књижевног језика, у којем се бави и етимолошком страном његовом. Уопште, Т. Лер Сплавињски посветио је цео низ етимолошких испитивања словенским језицима, тако да наша наука - ако после свих несрећа које су задесиле пољски народ остане у животу - може од њега, његове вредноће и широког познавања свих словенских језика очекивати и прави етимолошки речник словенски. Т. Лер Сплавињски заузима у чувеној Краковској лингвистичкој школи, коју су некада водили Развадовски [Розвадовски], Њич и Лос, данас заједно са проф. Њичем прво место. Његов организациони таленат окупио је наново око Славистичког годишњака нове, млађе снаге пољске које ће и његова издања и издања различних секција Пољске академије одржавати несумњиво на великој научној висини, коју је овај део пољске науке задобио баш радом краковских лингвиста и филолога међу којима Т. Лер Сплавињски заузима данас једно од првих места. Сматрамо да ћемо одати већ одавно заслужено признање Т. Леру Сплавињском, ректору Краковског универзитета, ако га изаберемо за дописног члана наше Академије. Академија философских наука једногласно износи овај предлог пред чланове целокупне Академије.

8.

Избор А. Вајана и Р. Јакобсона за дописне иностране чланове. Предлоге је образложио А. Белић. 14. јун 1955.

${ }^{7}$ Сплавињски је изабран за дописног иностраног члана 16. фебруара 1940. године. 
Прелази се на избор Андре Вајана, проф. Collège de France и ранијег проф. српског језика у École des langues orientales, у Паризу, кога је Одељење за литературу и језик кандидовало за дописног члана. Претседник даје детаљније обавештење о кандидату истичући да је он један од признатих иностраних слависта. Приступа се гласању и Претседник објављује да је д-р Андре Вајан, проф. Collège de France, изабран за дописног члана САН.

Затим се приступа избору Романа Осиповича Јакопсона, проф. Харвардског универзитета, кога је Одељење такође предложило за дописног члана. Претседник даје детаљније обавештење о кандидату. После гласања Претседник објављује да је Роман Осипович Јакопсон, проф. Харвардског универзитета, изабран за дописног члана САH.

9.

Биограбски лист изабраног кандидата А. Вајана. Попуюено Вајановом руком.

Nom de famille: Vaillant

Prénoms: André

Profession et titre officiel: Professeur honoraire du Collège de France

Directeur d'études à lécole pratique de la

Sorbonne

Établissement ou office: Retraité / Vice-Président de l'Institut

Adresse permanente: 37, Rue Pierre-Nicole, Paris V

Date et lieu de naissance: 3 Novembre 1890, Soissons

Date de l'élection pour le membre correspondant étranger de l'Académie Serbe: juin 1955

Appartenance aux autres académies (nom de l'académie, catégorie de membre, date de lélection - pour chaque académie separément): Académie Yougoslave de Zagreb

10.

Избор А. Мазона, Ј. Куриловича и В. В. Виноградова за дописне иностране чланове. Предлоге је образложио А. Белић. 17. децембар 1959. 
Претседник А. Белић износи предлог кандидације: Андре Мазон, професор Collège de France; Јиржи Курилович, професор Универзитета у Кракову; Виктор Владимирович Виноградов, редовни члан Академије наука СССР.

11.

Биографски лист изабраног кандидата Јиржија Куриловича. Писано Куриловичевом руком.

Nom de famille: Kurylowicz

Prénoms: Jerzy

Profession et titre officiel: Professeur de linguistique

Établissement ou office: Université de Kraków (Pologne)

Adresse permanente: Kraków, Podwale 1

Date et lieu de naissance: 26 . VIII 1895, Stanislavów

Date de lélection pour le membre correspondant étranger de l’Académie Serbe: décembre 1959

Appartenance aux autres académies (nom de l'académie, catégorie de membre, date de lélection - pour chaque académie separément): Institut de France (correspondant 1939, membre assedé $1964^{8}$ ), Académie Royale Danaise (1947), Académie de Science Pologne (1952)

Bojan Đorđević

\section{ALEKSANDAR BELIĆ AND FOREIGN SLAVICISTS IN THE SERBIAN ACADEMY OF ARTS AND SCIENCES}

\section{Summary}

The paper discusses original documents which propose the appointments of corresponding foreign members of the Serbian Royal Academy (Serbian Academy of Arts and Sciences), formulated, written and elaborated by Aleksandar Belić on the Academy sessions.

8 Овај податак о редовном чланству је очигледно накнадно додат, пет година после Куриловичевог избора у САНУ, уосталом другом руком и мастилом. 


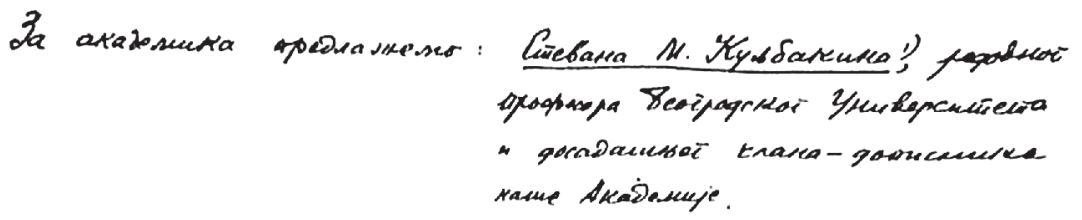

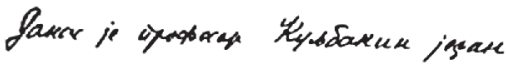

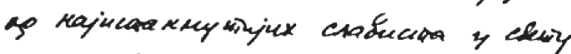

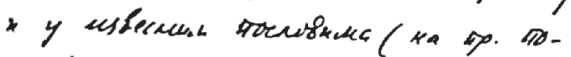


hencker jesure), nosupo, reajsasu.

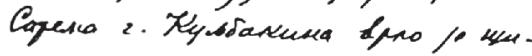
1) T. Keystarun je re causo Apropecad Teaxagekeon brum Mrameare kers \& ram ingasur. parea. Ore y cedes cjeburayje a ghe

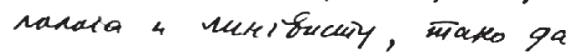
sa prerwhe kame orteadesuje wowhe Suon Sero Kopricisate.

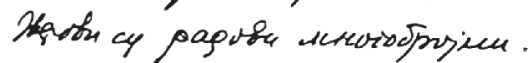
Des specuivurea of rain Ha yiro-

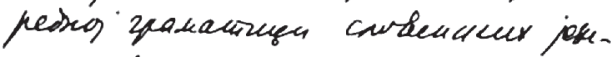
Na, istabavy a ipsysabery caqo. preprbeucuex serecurbe, " 4)w.

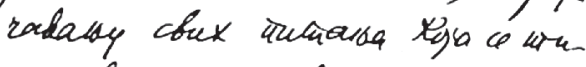
2y cafremenp sudencib nurbo. carsethe Gruarainge

Becopas, 16 jaryara 1025

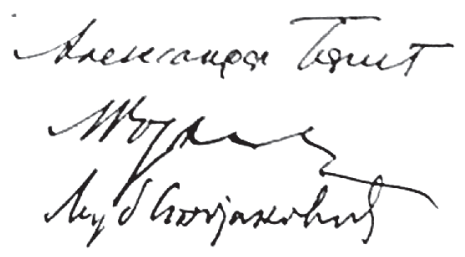

Предлог за избор С. Кульбакина за редовног члана. Писано руком

А. Белића, 16. јануара 1925. 